\title{
Liberais constitucionalistas entre dois centros de poder: Rio de Janeiro e Lisboa*
}

\author{
Maria do Socorro Ferraz Barbosa*
}

Este artigo trata de conflitos entre o absolutismo e o constitucionalismo tanto em Portugal como no Brasil; a província Pernambuco, entretanto, enfrenta problemas entre o constitucionalismo defendido pelo regente Pedro, no Rio de Janeiro, e o constitucionalismo dos vintistas portugueses. Os revolucionários sobreviventes de 1817 retornam ao poder dentro de uma perspectiva constitucionalista, mas monárquica.

Palavras-chave: Pernambuco - Constitucionalismo - Liberalismo

\section{Liberal Constitutionalists between two centers of power:}

Rio de Janeiro and Lisbon

This article is about the conflicts between absolutism and constitutionalism, both in Portugal and in Brazil. Pernambuco, in its turn, faced problems concerning the constitutionalism defended by the Regent Pedro, in Rio de Janeiro, and the constitutionalism of the twenties in Portugal. The revolutionaries of Pernambuco who survived the conflicts of 1817 , take back the power in 1821, within a constitutionalist yet monarquist perspective.

Keywords: Pernambuco - Constitutionalism - Liberalism

Libéraux Constitutionnels entre deux centres de pouvoir:

Rio de Janeiro et Lisbonne

Cet article étudie les conflits entre l'absolutisme et le constitutionalisme au Portugal et au Brésil. La province de Pernambouc affronte alors des problèmes entre le consti-

\footnotetext{
* Artigo recebido em outubro de 2007 e aprovado para publicação em dezembro de 2007.

** Professora do Departamento de História da Universidade Federal de Pernambuco. E-mail: slinsferraz@uol.com.br.
} 
tutionalisme soutenu par le Régent Pedro, à Rio de Janeiro, et le constitutionalisme des portugais des années vingt. Les révolutionnaires rescapés de 1817 reviennent au pouvoir avec une perspective constitutionnelle, mais monarchique.

Mots-clés: Pernambuco - constitutionalisme - Libéralisme

Previa Silvestre Pinheiro Ferreira ${ }^{1}$ que as exigências das cortes portuguesas reunidas em Lisboa, em 1820, causariam danos irreparáveis ao Império português. Estas exigências eram no sentido de fazer o rei, D. João VI, e o aparelho de Estado, instalado no Brasil, voltarem a exercer poder a partir da capital do Império, Lisboa.

Os brasileiros, de repente, viram-se sujeitos à obediência de leis, mandados e decretos vindos de dois centros de poder: o das cortes constitucionalistas, instaladas em Lisboa, e o da regência de D. Pedro, no Rio de Janeiro. Outra vez a nação luso-brasileira está dividida. Grande parte dos portugueses, radicados no Brasil, alinha-se com o poder das Cortes, em Lisboa, e parte dos brasileiros, principalmente os das províncias do Rio de Janeiro, São Paulo e Minas, fica solidária ao poder exercido pelo regente, no Rio de Janeiro. Este grupo, que mais tarde terá importância junto ao movimento pró-independência, apoiou a permanência de Pedro, futuro regente, mas não a continuidade de D. João VI, no Brasil. O conselheiro do rei, Silvestre Pinheiro Ferreira, através de 27 cartas, escritas a um interlocutor desconhecido, se pronunciou sobre a instabilidade política de Portugal e da Península Ibérica, sendo, portanto, favorável à permanência do rei, no Brasil; e, lembrando o destino da monarquia francesa, pergunta que papel exercerá o monarca português na assembléia constituinte de Lisboa? Terá direito a voz e a voto? Representará a aristocracia e/ou a nação luso-brasileira? O que acontecerá com o Brasil? Manter-se-á dentro do Império?

Como resposta a estas e outras indagações do conselheiro, o rei consulta a comunidade portuguesa no Rio de Janeiro e esta se pronuncia favorável a sua volta.

\footnotetext{
${ }^{1}$ Conselheiro de D. João VI, acompanhou-o quando de sua vinda ao Brasil em 1808. Atendeu ao rei em diferentes momentos, principalmente escrevendo Memórias sobre como passar do absolutismo ao constitucionalismo sem revolução. Desenvolveu também uma dissertação sobre a Teoria da Dependência, utilizando este termo no início do século XIX.
} 
A conjuntura política nesse período não propicia ao absolutismo português dar as cartas; mesmo que Napoleão já não estivesse em posição hegemônica, não havia mais clima para o revigoramento de monarquias absolutas. A situação da Europa havia mudado desde que Napoleão perdeu a guerra e as nações européias se reuniram em Viena, em 1815, para um rearranjo político naquele continente.

$\mathrm{Na}$ análise de Valentim Alexandre, ${ }^{2}$ para o período final do século XVIII e começo do XIX há uma forte expansão do comércio externo português, baseada na multiplicação de gêneros como cacau, algodão e arroz, que juntamente com o açúcar, todos produtos brasileiros, representavam $64,4 \%$ do conjunto das reexportações portuguesas para o estrangeiro. Segundo este autor, os produtos do Reino perfaziam 29\% das exportações. Este é o momento em que Portugal se aproxima de forma quase dependente da Inglaterra.

Antes, em 1777, as cortes de Lisboa se aproximaram das cortes de Madri e de Paris; entretanto, Portugal conservou as relações preferenciais com a Inglaterra. Estas alianças duraram até a explosão da Revolução Francesa, o que afetou este equilíbrio. Mas, a partir de 1803, ainda segundo Valentim Alexandre, houve uma recessão até 1807. Fatos, como a iminência da guerra, em agosto, entre Portugal e França, o bloqueio inglês desde outubro e a invasão francesa em novembro de 1808 causaram modificações na conjuntura econômica. A Grã-Bretanha, que era um dos maiores compradores de produtos portugueses ou reexportados por Portugal, de 1796 a 1801, cedeu o seu lugar para a França. Entre 1804 e 1807, a França passou a ser o maior importador de algodão vindo do Brasil.

A partir de 1807, com a invasão francesa em Portugal, e em 1808, com a transferência da corte para o Brasil, Portugal sofreu muitas turbulências: levantamentos populares contra as forças napoleônicas de ocupação, atropelos com a intervenção inglesa e, afinal, a guerra peninsular. Os portugueses, surpreendidos, constataram que o seu exército, aliás o que dele restou, estava comandado pelo general Beresford, responsável pela presença militar em Portugal. Abandonados a sua própria sorte e divididos em suas reivindicações, solicitaram aos franceses encaminhamentos com diferentes fundamentos ideológicos: os intelectuais pedem uma constituição a Napoleão, e a Junta dos Três Poderes, reunida em Portugal, sugere ao general Junot, comandan-

${ }^{2}$ Alexandre Valentim, Questão nacional e questão colonial na crise do antigo regime português, Edições Afrontamento, Porto, Portugal, 1993. 
te das tropas francesas, a nomeação de um príncipe para governar Portugal. Compreende-se a troca de "senhor" e a necessidade de ter governo legitimado por uma constituição, ou, no caso de uma nomeação, que seja realizada por quem está com a responsabilidade de reformar a sociedade e apoiar a burguesia porque o seu rei, seu governante, está no Brasil e o país ocupado por duas nações, em guerra.

A burguesia portuguesa fundada no exclusivo mercantil, queixava-se da conjuntura econômica, que lhe era desfavorável, e denuncia o Tratado de 1810, que atingiu sua indústria fabril e artesanal, e preparou-se para reagir quando houvesse uma conjuntura política mais favorável. Com o fim do bloqueio continental, tornou-se insuportável aceitar o Brasil como o centro do sistema. E, para desestabilizar esta situação, a volta de D. João VI seria imprescindível, assim como a criação de uma estrutura política que substituísse a antiga subordinada ao Rio de Janeiro.

Para tanto, criaram as Juntas Provisórias no Brasil, dentro do espírito constitucionalista das cortes de Lisboa. Estas nomearam presidentes, governadores militares e outros funcionários para as Juntas Provisórias, dentro do espírito constitucionalista. Esta nova ordem política não foi a solução para o Brasil, pois este Reino também estava dividido em relação ao centro de poder instalado no Rio de Janeiro e ao outro centro situado em Lisboa. Sem definição clara do limite de poder do Regente, as Juntas eram, na verdade, entidades desamparadas, utilizadas pelos dois centros de poder: Rio de Janeiro e Lisboa.

Com a volta de D. João VI para Portugal, o centro de poder do Rio de Janeiro dava sinais de esvaziamento, levando províncias como a Bahia, Maranhão, Pernambuco e Pará, com significativa parcela do comércio articulado ao comércio europeu, a elegerem Lisboa como centro de poder mais importante.

A imprensa, na época, percebeu a dificuldade que Portugal teria em manter a subordinação de sua mais importante colônia, agora reino unido. Durante algum tempo, foi o Brasil quem comandou a economia do Império e deu a Portugal trunfos para algum triunfo de sua diplomacia política.

Está enfim decidido que o Brasil vai ser um Estado soberano e independente; estão convocados os representantes do povo para decidir qual é a forma de governo que esse povo quer ter. 
Com estas palavras, Hipólito da Costa iniciava seu artigo no Correio Brasiliense, cujo título, "Constituição para o Brasil”, não agradou ao rei nem às cortes. Nesse assunto, estaria em conflito no Brasil, tanto o novo, representado pelo constitucionalismo das cortes, quanto o velho simbolizado pelo absolutismo do rei.

As cinco Cartas Régias, impostas pelas cortes, mas assinadas por D. João VI, faziam parte de uma política de retrocesso e tratamento menor dispensado ao Brasil. Se, de um lado, causaram indignação e riso, de outro, elas facilitaram às autoridades portuguesas a execução dessa política, nos locais de maior receptividade. O conjunto de medidas dizia respeito a cobrar a ausência dos deputados de Minas Gerais à Assembléia, em Lisboa; a ordenar a realização das eleições para as Juntas Governamentais Provinciais; a conceder ao príncipe a regência das províncias que lhe estivessem sujeitas; à nomeação de cinco ministros, substituindo os atuais de D. Pedro; a anular a Convocação do Conselho de Procuradores, responsabilizando os ministros autores desta Convocação, e abrir processo contra a Junta da Província de São Paulo.

A criação das Juntas Governamentais Provisórias, além de reduzir o poder do regente, pois a administração alfandegária e o comando militar ficariam sob a responsabilidade de Lisboa, favorecia o fracionamento da unidade, possibilitando lutas entre facções adversárias. Várias províncias, como já citado, por exemplo, Bahia, Maranhão e Pará, inclusive por terem governadores militares, quase que de imediato transferiram sua obediência às cortes e não permaneceram fiéis ao Rio de Janeiro. As províncias do Rio de Janeiro, São Paulo e Minas Gerais reagiram às cortes e se constituíram províncias regidas diretamente por D. Pedro.

Do ponto de vista da política das cortes de desestabilizar o Império brasileiro, a criação das Juntas tentava completar o esvaziamento do Rio de Janeiro como um centro de poder de outros subcentros. A reação do Rio de Janeiro, como centro de poder que almejava subordinar todas as províncias, foi rápida e se explicitou na pressão que exerceu sobre esses governos constitucionais provincianos, promovidos pelas cortes portuguesas, porém distantes de Lisboa. O governo do regente no Rio de Janeiro submeteu as Juntas Governativas Provinciais a uma fiscalização no âmbito político e econômico, com a presença de tropas militares e de funcionários da Fazenda Real. As tropas davam um suposto apoio aos partidários do poder localizado no Rio de Janeiro, naquelas províncias, cujas populações livres tinham maior 
contingente de portugueses que, articulados com o comércio externo de Portugal, poderiam ser elementos contrários aos partidários da Independência; as tropas também tinham a intenção de intimidar aquelas províncias, que alimentavam e demonstravam sentimentos separatistas. Como foi o caso de Pernambuco. Os funcionários da Fazenda Real eram na realidade agentes servidores aos propósitos do grupo do poder do Rio de Janeiro. Este grupo, usando da prerrogativa de o Rio de Janeiro haver sediado o governo do Império português, fiscalizava, através daqueles burocratas, o que as províncias deveriam enviar ao Rio de Janeiro em forma de tributo.

Na realidade, as Juntas, denominadas "reinóis" por Hipólito da Costa, não tinham base de sustentação na maioria da população, e o desaparecimento delas era uma questão de tempo, o que talvez tenha sido um dos propósitos das cortes na formulação de sua política "recolonizadora" para o Brasil. Entretanto, o surgimento dessas Juntas Governativas Provinciais trouxe, momentaneamente, benefícios para algumas províncias. Pernambuco, Bahia e Maranhão, por exemplo, não seriam mais obrigadas a "sustentarem o Rio de Janeiro", com o envio de homens para o exército, tributos que financiavam a luz do Rio de Janeiro, para usar a linguagem da época.

O general Luís do Rego, governador de Pernambuco após a Revolução de 1817, assumiu a presidência da Junta Provisória de Pernambuco; considerava as idéias liberais radicais dos pernambucanos atos insanos, baseados na literatura das revoluções francesa e americana. Aos sonhos de independência, que estas idéias escritas produziam no imaginário desses revolucionários, o referido general classificava-os como "contos loucos"; e, aos batalhões militares de respostas rápidas à guerra de guerrilha, organizados pelos pernambucanos, o mesmo general denominava de "fantásticas carrancas". De 1817 até 1820, o general Luís do Rego exerceu seu poder inconteste, em Pernambuco. Batidos pela repressão militar, os pernambucanos recuaram estrategicamente. Os sobreviventes da Revolução de 1817, prisioneiros ou livres, aguardaram uma melhor conjuntura para a retomada do poder, em sua província. Em nome do constitucionalismo, o general Luís do Rego devia ser afastado. Enquanto militar repressor e enquanto governador da província, representou o poder absolutista simbolizado na figura de D. João VI.

No mosaico político do Reino Unido do Brasil ao Reino de Portugal e Algarves, o general Luís do Rego e o conde dos Arcos eram reconhecidos como conspiradores contra as cortes, assim como a maioria dos governadores 
das Províncias do Brasil também o era. No quadro político interno, Luís do Rego não era partidário da Independência; portanto, o seu prestígio teria se perdido com o antigo regime. Sem elo, sem apoio, os pernambucanos aproveitaram para expulsá-lo.

Este processo de descolonização e simultaneamente de formação do estado nacional teve em Pernambuco um desdobramento sui generis: a experiência separatista da Revolução de 1817 custou-lhe muitas perdas: vidas, desorganização da produção, descrédito ideológico, divisão entre as elites; portanto, o momento exigia agir com muita habilidade para não se transformar em província reinol ou em uma província dependente do Rio de Janeiro. Pernambuco representava para a região Norte a mesma importância política que o Rio de Janeiro exercia na região Sul. Na correspondência entre os presidentes de províncias do Norte ou de governadores, durante os anos 1819, 1820 e 1821 e a presidência da Província de Pernambuco, percebe-se ser esta província um centro de poder para o qual convergiam informações e pedidos de ajuda sobre pirataria, armas, alimentos, roupas; ofícios, que acompanhavam presos políticos, presos comuns, militares desertores, a produção de açúcar para embarque, a do algodão e couros de outras províncias, pedidos de ajuda na guerra contra os gentios, pedidos de socorro contra os navios piratas, que roubam navios negreiros, e solicitações no envio de farinha para alimentar a tropa. Estas informações dão o termômetro do que representava Pernambuco para as províncias do Norte, um centro de poder administrativo, econômico e político.

Aos sobreviventes de 1817 seria mais cauteloso ganhar tempo, esperar a resolução dos acontecimentos entre Lisboa e o Rio de Janeiro, definidos entre a defesa do constitucionalismo português e uma independência contaminada pela hegemonia do Rio de Janeiro sobre as outras províncias. $\mathrm{Na}$ verdade, ambas as propostas subordinariam Pernambuco. Mas, na memória dos revolucionários sobreviventes o constitucionalismo português, através das cortes portuguesas, havia libertado os presos políticos de 1817, fazendo com eles, naturalmente, uma aliança, mesmo que fosse provisória. De certa forma, esta política de isolar as pretensões do grupo do Rio de Janeiro interessava aos liberais pernambucanos.

No jogo do poder, Luís do Rego ainda dava as cartas, mas estava bastante enfraquecido, desde que sua autoridade foi contestada com o aparecimento de uma Junta (constitucionalista) na cidade de Goiana, formada por pernambu- 
canos eminentes e frontalmente opositores ao general, exigindo a sua saída, juntamente com as tropas portuguesas que o apoiavam. Além desta exigência, a Junta de Goiana, representando boa parcela dos liberais pernambucanos, queria a reordenação das finanças e da administração, além da reorganização das forças militares. Nesse ponto, a Junta de Goiana se diferenciava das queixas e das reivindicações dos governos da Bahia, do Maranhão e do Pará, mesmo que em todas estas províncias os negócios fossem bem mais freqüentes, volumosos e rentáveis com alguns portos europeus do que com o Rio de Janeiro.

A adaptação do general Luís do Rego aos novos tempos é imediata. Em tempos constitucionais, soluções derivadas deste conceito serão tentadas. Convoca, em 30 de agosto de 1821, o Conselho Constitucional Governativo da Província de Pernambuco, que o elege neste mesmo dia presidente da Junta Governativa de Pernambuco. Tentou o general, através do Conselho, legitimar suas ações. Este enviou circulares às Câmaras da Província, informando a instauração do Conselho Governativo; solicitou informações à Câmara de Goiana sobre os acontecimentos naquela vila; solicitou ao general Luís do Rego a união dos corpos militares para reprimir Goiana; informou a Sua Majestade, D. João VI, “os acontecimentos e suas causas”; fez chegar a todas as câmaras da Província informações sobre a criação do Conselho e a insubordinação da vila de Goiana e enviou ofícios aos governadores das províncias vizinhas convidando-os a reconhecerem o governo chefiado pelo general Luís do Rego. ${ }^{3}$

\footnotetext{
3 "Acta da $1^{\text {a }}$ das Sessões do Conselho Constitucional Governativo da Província, 30 de agosto de 1821.

Às 6 horas da noite. Em conseqüência da eleição feita em Câmera no dia de hoje como consta do auto antecedente, se institui este Conselho Constitucional Governativo interinamente da Província, o qual achando-se reunidos com todos os seus membros, menos dois, que são o Senhor João Paulo de Araújo, e o Senhor José Carlos Mayrink da Silva Ferrão se reputou a sessão aberta; e todos os presentes procederão a prestar nas mãos do Presidente o juramento de cumprirem os seos deveres. Assim se executou.

Decidiu-se que se passassem circulares às Câmeras da Província, dando-lhes parte da instauração do Conselho Governativo.

Idem, que se officiasse à Câmera de Goyana pedindo-lhe a relação dos sucessos do dia 29 a declaração das medidas, e em virtude de que ordem.

Idem, que se proclamasse as gentes reunidas em Goyana exortando-os a recolher-se aos seos domicílios.

Idem, que o General desse as ordens que achasse necessárias para a reunião dos Corpos, e marcha deles em direção a Goyana, afim de persuardir-se mais breve aos povos que devem recolher-se.

Idem, que deste sucesso se desse parte a Sua Magestade assim como das causas que o produsirão e que a Câmera desta villa fizesse outro tanto, remettendo o termo que se lavrou, e os motivos que tornarão esta medida urgente.

E não havendo mais do que tratar, se deu por terminada a Sessão. Salla do Conselho Governativo, aos 30 de agosto de 1821. Barreto Moscôzo Moraes Oliveira Mendes Simoins Correia Caldas."
} 
A criação do Conselho tinha a finalidade de colocar Luís do Rego em uma situação confortável diante das cortes constitucionalistas. Mas, em $1^{\circ}$ de setembro de 1821, Luís do Rego apresentou ao Conselho uma ordem assinada por D. João VI com o seguinte teor:

Luís do Rego autorizo-o para fazer tudo o que entender que é a bem do meu serviço no desempenho desta Comissão e regule as repartições civis como se estabeleceu para a divisão do sul. Rio de Janeiro 2 de março de 1817. Majestade.

Com este documento, datado politicamente, tentava Luís do Rego eximir-se dos excessos praticados na repressão aos republicanos de 1817 e procurava uma legitimação para os seus futuros atos, principalmente no que diz respeito à repressão que desejava praticar contra a Junta de Goiana. Também, os constitucionalistas poderiam entender que o general continuava fiel aos absolutistas, defendendo o Rio de Janeiro como centro de poder articulado com a Inglaterra e não com Lisboa.

Habilmente, Luís do Rego assumiu o comando das operações militares e os outros componentes da Junta Governativa ficaram com os encargos civis. Goiana resistiu e logo se preparou para atacar a vila do Recife. Alguns batalhões militares aderiram à Junta de Goiana e outras tropas portuguesas permaneceram fiéis ao general, que se sentiu desamparado e ocultamente trabalhava por uma solução conciliatória.

Seu grande opositor não foi outro general e sim um comerciante, Gervásio Pires Ferreira, nascido em Pernambuco, na freguesia de S. Frei Pedro Gonçalves da cidade do Recife, em 26 de junho de 1765. Gervásio fez seus estudos primários até os 12 anos, em Recife, e depois foi enviado para completar os estudos de Humanidades no Colégio de Mafra, em Portugal; daí passou à Universidade de Coimbra, matriculando-se na Faculdade de Matemáticas. Escreveu o seu biógrafo Antonio Joaquim de Melo ${ }^{4}$ que uma oftalmia o retirou dos estudos mais aprofundados da matemática e comércio e o levou a estudar Direito, talvez como aluno ouvinte, naquela Universidade, ou aluno particular com algum jurisconsulto. O certo é que não terminou, também, seus estudos em Direito na universidade de Coimbra por problemas visuais, ainda segundo seu biógrafo. Após a invasão de Portugal pelos franceses e a conseqüente mudança do rei e sua corte para o Brasil em 1808, e, já casa-

${ }^{4}$ Biografia de Gervásio Pires Ferreira, Universidade Federal de Pernambuco, Editora Universitária, 1973. 
do, desde 1792, com D. Genoveva Perpétua de Jesus Caldas, em 1809 voltou ao Brasil no seu próprio navio, o Espada de Ferro. Negociante experiente na praça de Lisboa, onde atuou largamente, chegando a Pernambuco, iniciou seus negócios com outras nações. Foi por sua iniciativa que Pernambuco, pela primeira vez, estabeleceu comércio com Calcutá, levando e trazendo, em seus navios, mercadorias.

A sua fama, de homem entendido em comércio, credenciou-o a avaliar o sistema fiscal da república instalada em Pernambuco, em 1817, propondo reformas e melhoramentos.

As Proclamações do governo revolucionário não contêm sua assinatura, mas as autoridades responsáveis pela devassa o incluíram como participativo colaborador, tanto pelo conhecimento em questões práticas do comércio, como pela identidade ideológica com os liberais. Arroladas 22 testemunhas, a maioria o acusou de freqüentar o Conselho durante o Governo Revolucionário, principalmente quando se tratava de assunto sobre comércio e navios, de ser o responsável pelo Erário e de oferecer o seu navio Espada de Ferro para ir buscar na América inglesa mantimentos e armas. Em troca, teria recebido do governo revolucionário todas as caixas de açúcar pertencentes aos negociantes que haviam fugido. Outras acusações se seguiram, como: pertencer à causa da independência, tentar fugir para a América inglesa e, por fim, ser maçom.

Fracassada a revolução, Gervásio foi preso e enviado à Bahia, em um navio, denominado curiosamente Carrasco. Na Bahia, permaneceu mudo por mais de três anos. O tratamento recebido por ele e por outros revolucionários, desde os primeiros momentos de sua prisão, foi considerado por seus contemporâneos como humilhante. ${ }^{5}$ Da prisão, na Bahia, escreveu a sua mulher, D. Genoveva Perpétua de Jesus Caldas, e aproveitou esse instrumento para denunciar as maldades e injustiças cometidas contra ele, considerando a peça processual de acusação uma farsa. A carta, nesse sentido, é reveladora:

$\mathrm{Na}$ verdade, minha Rica, quem deixará de irritar-se à vista da falsidade com que uma dúzia de malvados, de mãos dadas, juravam na devassa a que se procedeu neste desgraçado país? Que o vil interesse levasse o homem a prostituir a própria mulher, a ser perjuro e assassino, disso nos apresenta a história das

\footnotetext{
5 "O Deputado por Pernambuco às Cortes Constituintes em Lisboa, Domingos Malaquias de Aguiar Pires Ferreira, disse na sessão de 13 de setembro de 1821: não há carcereiro mais ladrão do que o da Bahia. Estando preso naquela cidade Gervásio Pires Ferreira, um dos complicados na revolução de Pernambuco, teve que gastar alguns sete mil cruzados para alcançar que seu filho pudesse ir tomar-lhe a bênção", in Melo, Antonio Joaquim de, Biografia de Gervásio Pires Ferreira, Recife, Pernambuco, Editora Universitária (reeditado), 1973, p. 25.
} 
maldades do homem alguns exemplos; mas que doze homens se colocassem, sem motivo visível, a jurarem falsidade a torto e a direito, e assim cavarem a ruína de tantos chefes de família, isto custaria a crer se desgraçadamente não fosse uma verdade constante dos autos da Devassa.

Seria acaso a necessidade de encobrir os próprios crimes quem lhes lembrou a idéia de acusar deles aos outros para assim apartarem de si as testemunhas? Desgraçados! Não refletiram que eu não era homem para sofrer em silêncio suas calúnias. Graças a Providência que, privando-me do uso da voz e da escrita, me permitiu, contudo, esta para por seu meio responder em dezembro passado às perguntas feitas pelo Juiz da Alçada; e agora, nos cinco dias assinados, para dizer de fato e de direito, me concedeo um bom intérprete na nova língua de dedo para fazer a minha defesa! E esta imprimida como já o ordenei, fará pública e eterna a minha inocência no fato da rebelião de que me acusam, assim como os nomes, crimes e falsidades dos juramentos desses malvados.

Graças ainda outra vez à providência eles não reunião a tanta maldade do coração a perspicácia e talentos dos Plácidos, Lovalace e outros para que fosse dificultoso ou impossível desmascarar suas falsidades; e a sua mesma estupidez os atraiçoou. Para de uma e outra coisa fazeres uma justa idéia, basta que eu te diga que o Rego jura que eu e Antonio Carlos ${ }^{6}$ freqüentávamos o engenho do Morgado do Cabo; que José Antonio Gomes jura que quando eu vim de Lisboa, já era notado de Pedreiro livre, e que Bernardo José Carneiro Monteiro jura que eu, Antonio Carlos e o Juiz de Fora de Santarém tínhamos no Poço da Panela muitas conferências sobre revolução, co ele observou.

Por estes podes julgar dos juramentos de Manoel Soares, Zacarias, Joaquim José Vieira, Pedro Pinto de Miranda, José Antonio de Lemos Gomes, João Borges de Siqueira, Antonio Albuquerque, Antonio Ferreira Moreira, Manoel José Martins Ribeiro, José Roberto Pereira da Silva e Simão de Souza, testemunhas universais da Devassa, de muitas das quais tu ignoravas a existência; e para fazeres idéia da parcialidade da Devassa basta que te diga que nela só jurou ou a mais vil canalha ou os mais criminosos nos termos da Ordenação.

Felizmente estas verdades já vão aparecendo, e a minha defesa acabará de convencer ao público e à sua Majestade; e felizmente, superior a incômodos físicos e seguro na minha consciência espero que a minha sentença corresponderá aos meus desejos; assim como espero recuperar ao menos o uso da escrita para escrever a história da desgraça desse país, devida à temerária desesperação de quatro soldados e à fraqueza de uma multidão de oficiais generais, a quem sua Majestade pagava para defender os seus direitos e proteger os seus pacíficos vassalos. Entretanto, que os destinos me retêm nesta prisão, escola a mais instrutiva do caráter e vícios do animal homem, espero que me faças a justiça de crer que sou o - Teu Amigo - Gervásio pires Ferreira.

${ }^{6}$ Gervásio refere-se a Rego, João da Silva Rego, capitão de milícias, e a Antonio Carlos de Andrada, ouvidor de Olinda, nesse período. 
P.S. Abraça de minha parte os nossos filhos, agradece a lembrança que tuas cunhadas me enviaram por via de João de Deus e recomenda-me a José Alexandre, João Félix, primo Joaquim e a nossa Isabel. ${ }^{7}$

A carta de Gervásio Pires a sua mulher permite alguns comentários.

Pela estrutura e teor conteudístico, não se trata de uma correspondência modelar, do século XIX, entre dois amantes; não há juras de amor, nem saudades choradas. Seria incomparável às cartas que trocaram entre si o general Bolívar e sua amante Manuela Saens. Trata-se de um documento de defesa cuja estratégia escolhida foi a acusação. No primeiro momento, surpreende-o a acusação de pessoas qualificadas, como militares, comerciantes, e a sua resposta, portanto, trata de confundir a informação, expondo a insanidade da denúncia e realçando a posição social, econômica e ou política dos companheiros de infortúnio. Por exemplo, ao citar Antonio Carlos de Andrada, ouvidor de Olinda, estaria lembrando que o mesmo é irmão de José Bonifácio de Andrada e pondo dúvida em relação a uma possível participação de Antonio Carlos entre os revoltosos; e, ao se referir ao Juiz de Fora, de Santarém, o leitor ou as autoridades poderiam desconfiar de acusações feitas sobre um juiz português, cúmplice de revolucionários da terra. A desqualificação das "testemunhas universais", como peçaschave do processo, é bastante convincente porque indica o pertencimento delas a uma categoria subserviente aos interesses das autoridades responsáveis pela Devassa. Por fim, responsabiliza a incompetência da burocracia militar, seja portuguesa, seja brasileira, pelos acontecimentos e reduz a "quatro soldados" oficiais brasileiros, que se rebelaram contra a dominação portuguesa.

Há duas acusações a Gervásio que se destacam: que ele, Gervásio, participava das reuniões do Conselho quando a pauta incluía assuntos de comércio e navios e que já pertencia à loja maçônica dos Pedreiros Livres antes de vir para Pernambuco. Tudo indica que estas acusações eram procedentes. As suas atividades evidenciam estas possibilidades. No processo estabelecido pelas autoridades portuguesas constam vários depoimentos que confirmam a relação de Gervásio Pires com os dirigentes revolucionários e a sua desenvol-

${ }^{7}$ Melo, Antonio Joaquim, op. cit., p. 26 e 27. 
tura nas relações políticas e financeiras com comerciantes dos Estados Unidos. ${ }^{8}$ Próspero negociante da praça de Lisboa, ao chegar a Pernambuco, articulou-se com um grupo de comerciantes de tendência política liberal. Era um cidadão com todas as características de quem repudia o absolutismo. Na prisão da Bahia, o juiz da Alçada, que presidiu o processo em que foi acusado de participação na Revolução de 1817, fez, além das perguntas de praxe, onde nasceu, se é casado etc., outras, mais comprometedoras, como por exemplo: por que foi

\begin{abstract}
${ }^{8}$ Documento apenso no processo, fl 7.
"Patriotas Governadores Provisórios. A vossa presença apresenta o Suplicante Gervásio Pires a relação das pessoas por quem se distribuíram, na conformidade das vossas ordens de 9 do corrente, 224 barricas de farinha e 12 de bolacha, parte da carga do Bergantin Americano, descarregado no armazém do Forte do Matos e que, por comodidade do público, em razão da distância da moradia do Suplicante houvesse por bem encarregar ao patriota Bento José da Costa. Nestes termos incumbe-vos ordenar ao Tesoureiro do Erário haja de receber a quantia de 4:614\$000, produto das vendidas, e ao patriota Bento José da Costa que receba as exixtentes, passando as clarezas necessárias. - Despacho. - Remetida ao patriota Bento José da Costa para tomar conta da mencionada farinha e fazê-la repartir por vendas, como julgar conveniente à necessidade pública. Casa do Governo 28 de março de 1817. - Pessoa de Melo - Mendonça-Martins - Correia.
\end{abstract}

Apenso A. fl. 68

Certidão das perguntas de Reculet, francês, relativamente a Gervásio Pires, passada pelo Desembargador João Osório de Castro Souza Falcão.

Certifico e dou fé, que vendo os autos de perguntas feitas a Reculet, francês, em trinta e um de Janeiro de 1818 na vila do Recife de Pernambuco e Fortaleza das Cinco Pontas, neles consta a resposta do teor seguinte - respondeu chamar-se Pedro Remígio Reculet, natural de Tionvile da Nação francesa, de idade de 26 anos, que sua ocupação era militar na França e que foi Alferes, e lhe aceitaram sua demissão em Janeiro do ano passado, e que depois fora para a cidade de Namur para a casa de um seu cunhado que era advogado, e, querendo aplicar-se à vila do comércio e achando que nesta cidade não está florente, se resolveu ir para a América Inglesa, aonde chegou e desembarcou na Nova York em Março de 1817, e, não achando ali boa acomodação de caixeiro, se uniu ao capitão Arthong que foi para o Rio de Janeiro, e então na América estava unido ao Coronel Lutapé, e que pretendia empregar-se no serviço militar aonde o quisessem, e na mesma tenção que eles tinham ficou ele respondente; e chegando aí a Boston o embaixador da República de Pernambuco, chamado Antonio Gonçalves da Cruz, um Comerciante desta cidade, correspondente ao dito Embaixador, escreveu a Mr. Chegaré, na Filadélfia, para lhe noticiar alguns oficiais militares de merecimento que o dito Embaixador pretendia enviar para a dita sua República, e então este Chegaré comunicou este projeto ao coronel Lutapé, e depois disso chegou a Filadélfia o dito Cruz e se ajustou com Lutapé para vir para Pernambuco com ele, respondente, dito Arthong, e para esse fim tornara a Nova York para ajustarem embarcação para a passagem para Pernambuco; e ele dito respondente foi quem ajustou uma Casa de Comércio Americana Itaw Robbens para virem na Chalupa Patagônia eles três e mais um outro, segundo lhe mandou Lutapé, e depois viu ele respndente que esta quarta pessoa era Luiz Adolfo, Conde de Gente Coullant, e que ele respondente antes não conhecia; porem apareceu aí com uma carta do Marechal Cruche para que o dito Lutapé o trouxesse consigo para Pernambuco por assim ter ajustado com o dito Antonio Gonçalves da Cruz, e com o dito Conde veio um filho do dito Marechal Cruche que lê respondente conhecia de vista, posto que lhe não sabe o nome, e embarcaram todos a bordo da dia Chalupa para Pernambuco, à custa do dito Antonio Gonçalves da Cruz, em 15 de Junho passado, o qual deu Cartas de guia e correspondência ao dito Lutapé, o qual à beira da terra lançou ao mar, vendo que a terra não estava pela República; e disse ele respondente que na Chalupa vinham 1.500 espingardas, 500 pistolas, 500 sabres de cavalaria, muito breu e alcatrão, e uma caixa fechada que lê respondente não sabe o seu conteúdo, mas tudo comprado pelo dito Antonio Gonçalves da Cruz e remetido a Gervásio Pires Ferreira, negociante de Pernambuco, segundo a descrição que ele respondente viu no livro da carga e nos conhecimentos que lhe foram mostrados pelo Capitão da Chalupa e por saber inglês, e quem comprou tudo isto por ordem do dito Cruz foi um negociante Lott Seamen, seu correspondente. - E nada mais havia nas ditas perguntas, que fosse relativo ao R. Gervásio Pires Ferreira.” 
preso, em que cargo esteve empregado pelos rebeldes e que serviços realizou, e se comparecia às reuniões do governo revolucionário, por que sustou a viagem do seu navio à Ásia? O réu respondeu: que não sabia a razão, que era um comerciante, que os seus livros estavam corretamente escriturados e que nunca tinha praticado o contrabando, ação tão ordinária na sua classe; que a idéia de revolucionário é incompatível com a de comerciante abastado de bens de fortuna, porque, segundo ele, ao menor transtorno da ordem pública, os comerciantes são atingidos imediatamente. Encontrava-se em casa, fingindose de doente para evitar maior participação no governo dos rebeldes quando foi surpreendido por sua prisão. Que prestou serviços aos rebeldes por força das baionetas apontadas para si; provavelmente pela sua experiência, inteligência para o comércio e ter crédito no mundo do comércio. Isto o credenciou a ser útil ao novo governo. O chefe Martins ordenou que extraísse o balanço das contas públicas, organizasse e emendasse o balanço das rendas públicas, ficasse responsável pela compra e venda dos carregamentos de farinha e ainda apresentasse um projeto sobre o melhoramento, que pudesse ocorrer na administração da Companhia de Pernambuco; que foi instado, juntamente com outros comerciantes, como Bento José da Costa, a importar mercadorias da América inglesa, em especial mantimentos sob a responsabilidade do governo. Foi obrigado a examinar diversas folhas de despesa da Intendência, Trem e Ferraria de S. Majestade, isto é, do governo do general Luís do Rego e, nessa avaliação, encontrou roubo. Que não participou de conferências com o governo e nunca foi nomeado conselheiro, nem fez reuniões em sua casa, pois era a única que tinha lampião para iluminar a entrada e que é uma das moradias de Pernambuco que abrigava uma das famílias mais numerosas. Afinal, descreve um pouco sobre sua vida, tentando provar que se fez a si mesmo, pois desde os 11 anos, quando foi para Lisboa, lá permaneceu até homem-feito. Estudou, trabalhou, casou e foi negociante matriculado na praça de Lisboa até 1809 , quando voltou a Pernambuco.

As acusações mais graves estavam dirigidas ao fato de haver colocado seu navio Espada a serviço dos revolucionários. Gervásio tenta envolver outros personagens, como Bento José da Costa, explicando os seus negócios em sociedade com este comerciante, nos carregamentos de 300 fardos de fazenda, em Bengala. Também não suspendeu a viagem do seu navio Espada a Goa; esse porto estava vedado por ser do domínio de S. Majestade o rei de Portugal. Para não ter grandes prejuízos, aceitou a imposição do governo 
revolucionário em trazer da América inglesa farinha, queijos e manteiga. $\mathrm{O}$ valor total desse carregamento não chegava à metade do que ele receberia nas transações com a Ásia.

Apesar das comprometedoras acusações, foi julgado, condenado e incluído no perdão da Carta Régia de 9 de março de 1819. Libertado em 22 de fevereiro de 1821, por influência dos ventos constitucionalistas da Revolução do Porto, voltou para Pernambuco e continuou a sua atividade de comerciante. Mais do que exercer a atividade de comerciante, encontramos outra vez Gervásio na vida pública e política da província.

$\mathrm{Na}$ discussão das cortes constitucionais de Lisboa sobre administração do Ultramar, uma solução deveria ser dada no sentido de uniformizar a administração entre Portugal e Brasil. O posto de governador, além de ser relacionado ao antigo regime, não encontrava correspondência em Portugal; portanto, as cortes o substituíram por Junta Provisória, que seria o resultado de uma eleição na província, confirmada pelas cortes constitucionais. As Juntas teriam uma administração mais colegiada e relacionada com o novo governo constitucionalista português.

O decreto de $1^{\circ}$ de outubro de 1821 estabeleceu a criação das Juntas Provisórias nas Províncias do Brasil. Recém-eleitas dentro do espírito constitucionalista, os cargos de presidente e secretário foram geralmente preenchidos por brasileiros, que se sentiam vigiados por militares portugueses e reduzidos a simples fiscais dos tributos alfandegários portugueses. Além de reduzir o poder do regente Pedro, pois a administração alfandegária e o comando militar ficariam sob a responsabilidade de Lisboa, a criação das Juntas, com este formato, favoreceu o fracionamento da unidade brasileira. Várias províncias, como o Pará, a Bahia e o Maranhão, preferiram, quase que de imediato, transferir sua obediência às cortes e não permaneceram fiéis ao rei. As do Rio de Janeiro, São Paulo e Minas Gerais, aliadas, reagiram à autoridade de Lisboa e se constituíram províncias regidas diretamente pelo governo do Rio de Janeiro. Pernambuco, com a experiência separatista que lhe havia causado muitas perdas de vidas, desorganização da produção e descrédito ideológico, necessitaria de muita habilidade para não se transformar em uma província reinol ou em uma província dependente do Rio de Janeiro.

Com as mudanças advindas de Lisboa, o general Luís do Rego logo se colocou na condição de constitucionalista e se fez presidente da Junta, após convocar o Conselho da Província, em 30 de agosto de 1821, durante 
a eleição realizada na Câmara. Entretanto, já havia uma reação no interior da província contrária à permanência do general Luís do Rego como autoridade governativa. A Câmara de Goiana, em 29 de agosto de 1821, instalou um Governo Constitucional Temporário, presidido por Francisco de Paula Gomes dos Santos que, entre outras medidas, intima o governador Luís do Rego a deixar a província.

Teobaldo Machado 9 analisa a política de Goiana, tomando como base a política de retaliação do general Luís do Rego, e aponta a derrota da Revolução de 1817 como fator de desmobilização da economia naquela comarca. Por exemplo: o comércio das carnes verdes levava os que faziam esta atividade a abastecer várias vilas da província, inclusive Recife. O comércio, aliado à atividade agrícola da cana-de-açúcar, dava a Goiana relativa prosperidade. Um imposto que incidia sobre as carnes verdes levou os goianenses a apoiar a Revolução de 1817. Durante o governo de Luís do Rego, não apenas o imposto continuou a ser cobrado, como a Vila de Vitória de Santo Antão passou a fornecer carnes verdes para o Recife, abalando, financeiramente, sua concorrente Goiana. Outras retaliações aos goianenses podem ser percebidas em várias ações do governo de Luís do Rego: a vila mantinha uma importante atividade de artesanato, que se fazia através da fiação e tecelagem de panos, grosso; Luís do Rego propõe a D. João VI a substituição dessa atividade informal por uma fábrica moderna de fiação, com o apoio dos grandes proprietários de engenho de açúcar da região. Outro episódio, que parece ser fruto do comportamento violento de Luís do Rego, transformou-se em uma demonstração de poder, trazendo vexame àquela população: a substituição das urupemas, ${ }^{10}$ nas janelas goianenses, por outros elementos que pudessem servir de anteparo ao sol. É fato inusitado que um governador vá a uma vila, à noite, mande arrancar todas as urupemas que se penduravam nas janelas e depois faça com elas uma grande fogueira.

Tanto Teobaldo Machado quanto Gilberto Freyre levantam a hipótese de que a atitude desse governador tivesse sintonia com as mudanças nos usos e costumes e interesses nas compras de produtos ingleses. Sem as urupemas, os goianenses foram obrigados a comprar vidros ou grades de ferro. Sobre a futura fábrica de tecidos, Luís do Rego, que conhecia a legislação e a prática de instalação de indústria na colônia, sabia da sua impossibilidade, o que leva

\footnotetext{
${ }^{9}$ Machado, T. As insurreições liberais em Goiana, Recife, Fundarpe, 1990.

${ }^{10}$ Trançado de fibra vegetal usado como anteparo ao sol nas janelas das casas.
} 
os autores a deduzirem que a sua pretensão era, simplesmente, a destruição dos teares de Goiana.

A Junta de Goiana organiza a ação militar e anuncia que vai marchar sobre o Recife. A démarche para a conciliação, promovida pelos desembargadores Antenor José de Maia e Maciel Monteiro, foi vã.

O impasse político-militar entre a Junta de Goiana e a Junta de Pernambuco presidida pelo general Luís do Rego teve o seu epílogo na praça de Beberibe, local de confluência entre Recife e Olinda, com o aval do comerciante Gervásio Pires, que retomou a fala, perdida três anos antes, quando da sua prisão. O episódio é conhecido como a Convenção de Beberibe e deu a Gervásio Pires a oportunidade de se reencontrar com a política.

O governo constitucionalista de Lisboa aceitou o encaminhamento que os liberais deram ao conflito e, através do ofício de 15 de outubro de 1821, autorizou a instalação do novo governo constitucional para a província. Em 26 de outubro do referido ano, o ex-governador Luís do Rego embarcou para Lisboa, juntamente com parte de sua tropa, e no mesmo dia foi eleita a Junta Governativa Provisória de Pernambuco, da qual Gervásio Pires Ferreira figurava como presidente. É curioso notar a constituição desta Junta: Gervásio Pires Ferreira, presidente, Pe. Laurentino Antonio Moreira de Carvalho, secretário; membros, Manoel Ignácio de Carvalho, Antonio José Vitorino Borges da Fonseca, Filipi Néri Ferreira, Joaquim José de Miranda e Bento José da Costa. Todos eram liberais, participantes de uma forma ou outra dos conflitos com o absolutismo e sobreviventes da Revolução de 1817.

Enquanto a Junta Provisória se organizava, o governo de Lisboa, sorrateiramente, deslocava de Portugal um novo Governador de Armas, para Pernambuco.

A Junta presidida por Gervásio Pires enfrentou uma tarefa difícil e delicada na comunicação de sua instalação aos dois centros de poder: às cortes, em Lisboa, e ao governo do Rio de Janeiro. As primeiras providências tomadas diziam respeito ao restabelecimento da ordem, e para isso o novo governo contava com o apoio militar: o comandante das forças militares de Goiana deveria manter a mobilização; o comandante do segundo Batalhão da vila do Recife era elogiado pela manutenção da ordem, mesmo depois da saída de Luís do Rego. Ordenava-se destruírem-se todas as trincheiras e consertarem-se os estragos feitos por Luís do Rego. Recolhiam-se as armas, fazendo-se com que voltassem ao arsenal de onde saíram. 
Entretanto, a província ainda não estava apaziguada. A existência de tropas portuguesas aquarteladas no Recife, aguardando embarque para Lisboa, juntamente com suas famílias, e a presença de tropas pernambucanas, mantidas longe de suas casas e famílias, desde o início da guerra, exigiam das autoridades cautela no sentido de se evitarem enfrentamentos mútuos. Apesar de a população do Recife e do próprio governo não se sentirem protegidos pelos Corpos Militares portugueses, não desejavam novos combates e baixas. A providência imediata seria apressar o embarque das tropas lusas; o conhecido $2^{\circ}$ Batalhão de Fuzileiros do Algarve recolhido ao Bairro do Recife e aquartelado no Convento da Madre Deus, pela proximidade do cais, aguardava o embarque. Uma última manobra dos comerciantes portugueses solicitava sua permanência, por representarem boa fatia do mercado interno consumidor. Um abaixo-assinado, com mais de cem nomes de negociantes portugueses, solicitou ao comandante da fragata, responsável pelo transporte desses batalhões, que se opusesse ao embarque dos soldados portugueses. O comandante, cautelosamente, encaminhou à Junta o petitório para que ela deliberasse, e, na sessão seguinte, os oficiais foram chamados para organizar o plano de embarque das tropas portuguesas.

Segundo o redator das atas da sessão do dia 29 de novembro de 1821 do Governo Provisório de Pernambuco, as escaramuças e desordens provocadas pelos soldados do Batalhão do Algarve exigiram que soldados do $3^{\circ} \mathrm{e} 4^{\circ}$ Batalhões de Milícias reforçassem a guarda principal, numa demonstração da existência de uma força militar pernambucana. No dia 30 de novembro a Junta deu ordens ao coronel comandante do Batalhão do Algarve que embarcasse às duas horas da madrugada. Mesmo com a saída dos militares portugueses, o governo ainda temia represália aos civis portugueses ou a alguma tropa que houvesse participado da repressão comandada pelo general Luís do Rego. Por esta razão foi cautelosa a redistribuição da guarnição aquartelada em Olinda e também das milícias de Olinda e Afogados.

A província estava em uma situação caótica em assunto de organização militar: rivalidades entre militares, luta de militares em diferentes frentes, soldos desiguais para serviços idênticos e batalhões organizados intempestivamente no calor do embate com milicianos oriundos de diferentes corpos militares. Após a saída dos batalhões portugueses, o poder militar ficou até certo ponto esvaziado. O poder constituído tratou de organizar uma força militar com raízes sócio-raciais na província. Foram criadas duas compa- 
nhias de pretos e duas companhias de pardos, que recebiam soldos por este serviço e que fossem comandadas por sargentos-mores da mesma raça e classe, respectivamente. Na mesma determinação, criavam-se duas companhias de brancos. O fato novo, nesse ato administrativo, é o recebimento de soldo pelos militares das companhias de pretos e pardos. Isto tem fundamento no pensar revolucionário da época; como as tropas de linha recebiam soldo, as tropas nativas também receberiam. Em algum momento seriam iguais. Gervásio e os outros membros da Junta tinham pressa na organização da província, antes que chegasse o novo Governador de Armas.

O discurso de Gervásio Pires Ferreira na abertura da primeira sessão da Junta Governativa de Pernambuco é o termômetro do que pensavam os liberais sobreviventes à Revolução Republicana de 1817.

[f.26 v.] Sessão $1^{\mathrm{a}}$ em o dia 27 de 8 bro [outubro de 1821]

Abriu-se a Sessão com o seguinte discurso do Senhor Presidente:

Reunidos, Senhores, neste lugar por voto dos nossos concidadãos para dirigirmos a barca da administração pública ao porto da nossa comum felicidade, e desde logo nomeado para presidir as vossas deliberações, confesso ingenuamente que se me magoa o deplorável estado de podridão de suas partes mais essenciais pelos desvairados caprichos da arbitrariedade dos tempos passados, e se me assombra a vasto mar que temos de navegar, ainda ressentido das últimas tormentas; eu me sinto contudo possuído d'huma tão nobre ufania pela honra da escolha e diviso nos semblantes de Vossas Senhorias sentilar tão vivamente o fogo electrico (sic) do Patriotismo Constitucional que contando com a poderosa cooperação de Vossas Senhorias não receio que deixemos de tocar o porto desejado. Embora muitas das nossas manobras por falta de prática da navegação de tão altos mares não seja as mais apropriadas as circunstâncias da monção e mesmo nos desviem por instantes de nosso verdadeiro caminho a observação porém, o desejo de acertar, a prudência de Vossas Senhorias [como] o melhor Cronômetro político nos indicará o rumo que devemos seguir. Conheço bem, Senhores quão árdua he a tarefa mormente na posição delicada em que se acha este país a pouco combalido violentamente pela intriga de alguns malvados que à força de embustes e aleives nos quiseram dividir para melhor nos assacinar; firme porém nos princípios que sempre regularam as minhas accões, superior a toda rivalidade que não tenha por objeto o serviço da nação e d'El Rei não me assombram ad dificuldades e confiado na cooperação de Vossas Senhorias, que tanto mereceram da pública confiança e em que o Soberano Congresso fazendo justiça à pureza dos nossos sentimentos nos revelará os mesmos erros que não pudermos evitar, por não estarem ao alcance dos nossos conhecimentos. Eu de antemão me congratulo com Vossas Senhorias de que não havemos desmerecer a confiança que se há de nós fei- 
to. Guiados pelo patriotismo Constitucional que nos anima e à Luz da razão e experiência do passado não devemos recear os escolhos que o egoísmo dos áulicos tem sabido espalhar pela estrada da verdade. Devendo portanto dar princípio desde logo a nossa tarefa e deixando aos historiadores o cuidado de fazerem o triste quadro de nossas passadas desgraças e de o transmitirem aos nossos vindeiros para sua instrução, não posso deixar de apresentar quanto antes à consideração de Vossas Senhorias que devendo estar o Soberano Congresso e El Rei suspenso sobre a verdadeira direção dos movimentos da província pelas sugestões dos áulicos que por conservarem o mando procuram infamar a nossa fidelidade, devemos participar imediatamente a El Rei e as Cortes Gerais, Extraordinárias e Constituintes da Nação Portuguesa: primeiro, que os movimentos da Província tendo por motivo a escandalosa insultante arbitrariedade do Ex-General e em vista a Proclamação do Soberano Congresso aos Povos do Brasil, tendiam a exemplo dos nossos Irmãos de Portugal a afastar o despotismo de nossas praias e a instalar hum governo constitucional como o que se acha estabelecido e que o Governo que a necessidade das circunstâncias abrigou a criar temporariamente para a manutenção da ordem pública, correo de longe e contente a depositar nas mãos desse governo o mando das Câmaras, que o tinham reconhecido. Segundo: as últimas ciladas que a intriga armou à credulidade dos habitantes do Recife para induzir alguns cidadãos pacíficos a uma intempestiva expatriação. E terceiro: que os Pernambucanos, qualquer que tenha sido o local de seo nascimento, correspondendo aos sentimentos dos vogaes que formam o seo governo morrerão primeiro que vejam outra vez o despotismo pisar a Pátria dos Vieiras, Vidaes e Dias; e que ligados aos seos irmãos de Portugal pelas mais estreitas relações de sangue e muitos interesses unem igualmente suas vozes e de seos Deputados para protestarem a mais firme adhesão e fidelidade às Cortes Extraordinárias Constituintes da Nação Portuguesa e a El rei Constitucional o Senhor Dom João $6^{\circ}$ e a sua Real Família Via a religião, as Cortes e El Rei.

O discurso de Gervásio Pires Ferreira demonstra em primeiro lugar a vontade de os pernambucanos serem aceitos no Império como súditos, mas deixa bem claro que estes súditos fizeram há muito tempo uma opção pelo constitucionalismo. Reconhece erros, que não puderam ser evitados, cometidos no passado. Divide as responsabilidades desses erros com "malvados, embusteiros e mentirosos" que tinham como objetivo dividir a nação portuguesa. E, recorrentemente, acusa os áulicos e o despotismo como fatores de discórdia e desconfiança entre o rei e os pernambucanos, que intempestivamente, segundo ele, caminharam para uma expatriação. Não há alusões ao príncipe regente no Rio de Janeiro. As cortes constitucionalistas são o norte para a Junta Governativa de Pernambuco. Veladamente aparece uma advertência: 
os pernambucanos preferem morrer a aceitar outra vez o despotismo destruir sua pátria. É uma alusão explícita ao governo do general Luís do Rego; seria um anúncio antecipado da Confederação do Equador?

As relações de Gervásio Pires com o governo do Rio de Janeiro foram, desde o começo, tensas. Em seu discurso de posse na presidência da Junta, já se referia ele às rivalidades existentes no país. É na afirmativa de que não existia intenção de independência que o mesmo se coloca diante das autoridades portuguesas e das do Rio de Janeiro; mas, é na convocação do Conselho da Província, que decide sobre o desembarque das tropas portuguesas, que ele se denuncia. A situação é difícil e já havia sido prevista em seu discurso de posse. A defesa que fez sobre as acusações de "independência" é mais alusiva aos interesses do Rio de Janeiro do que às relações com Lisboa. Segundo as proclamações feitas, seja pela Junta, seja por Gervásio, o jogo do equilíbrio entre os dois pontos (Lisboa e Rio de Janeiro) fora sempre muito perigoso para Pernambuco.

Em 16 de fevereiro de 1822, o príncipe regente decreta a criação e convocação do Conselho de Procuradores Gerais das Províncias, para atender requerimento dos mineiros, paulistas e fluminenses. Isto era uma resposta às cortes pela criação das Juntas Governativas Provinciais e de certo modo uma tentativa de anular ou obstaculizar toda e qualquer iniciativa proposta pelas Juntas; cabia ao Conselho examinar propostas de reforma na administração em geral, assim como de medidas e planos relacionados ao desenvolvimento do país.

A reação da Junta de Pernambuco foi de extrema desconfiança. Além do surgimento de um poder paralelo ao poder das Juntas, as notícias que chegavam do Rio de Janeiro davam conta de que o regente "daria uma constituição ao Brasil diferente da de Portugal”, sem, entretanto, se desintegrar da monarquia portuguesa. Ademais, Pernambuco alimentava sérias queixas contra o mando dos Andrada, visto como a mais forte tendência centralizadora. A Junta respondeu a uma comunicação de José Bonifácio, dizendo que o governo de Pernambuco não apoiaria nenhuma iniciativa da regência sem antes ouvir o soberano Congresso; recomendava, ainda, a Sua Alteza Real, o Príncipe, desconfiar de ministros que aconselhavam medidas dessa natureza. Uma dessas medidas dizia respeito às questões dos destacamentos militares que estavam estacionados no Rio de Janeiro e em Montevidéo. Estas tropas estavam ali desterradas, como castigo, por haverem eles ou algum parente participado de 
movimentos revolucionários. Uma carta, publicada anos depois (em 1832) no periódico Bandeira de Retalhos, em Pernambuco, dá-nos a idéia dos limites e das dificuldades por que passavam aqueles que se viam, de uma maneira ou de outra, envolvidos com os conflitos políticos do seu tempo. Vejamos na íntegra os argumentos de

Joaquim Ignácio de Barros Lima, $2^{\circ}$ tenente de Artilharia, aquartelado no Brum, leva ao conhecimento de V. Excia. Francisco de Carvalho Paz de Andrade, Presidente da Província de Pernambuco, que sentou praça no extinto regimento de Artilharia de Pernambuco, em 14 de fevereiro de 1812. Foi mandado, como em degredo para Monte Vídeo e a julho de 1817, por motivos de acontecimentos políticos dessa Província; e não sofrendo o suplicante só esta pena, viu mais ser enforcado seu Pai (José de Barros Lima) e toda a sua família seqüestrada: o Suplicante, pois em seu degredo, vítima (como ainda hoje) dos caprichos, e rancores dos mandatários Portugueses, sofreu todas as privações e insultos anexos as suas tristes circunstâncias, até setembro de 1822; tempo em que o General Visconde da laguna, se fez brasileiro para angariar partido, aclamar Pedro I, e jurar a Constituição que fizessem as Cortes Brasileiras; e como seu fim era agradar naquela época para alcançar o que desejava lançou mão do Suplicante e de outros pernambucanos e despachou os Oficiais em 22 de janeiro de 1823, quando as tropas brasileiras se achavam em Campanha na Cisplatina, para lançarem dela o exército português e estabelecerem o sistema da Independência jurada: neste tempo, o Suplicante e seus companheiros foram tratados com a maior distinção, e aquele General malicioso, e seus comensais lhes prodigalizavam louvores honrando-os com o título de bons patriotas; mas apenas caiu a Constituinte em novembro daquele ano quando o Suplicante, que já não era necessário, viu-se em novo abatimento e foi outra vez tratado de anarquista e republicano. Contudo, como eram escassos os Oficiais de sua arma, ele foi mandado destacar com uma companhia para a Praça da Colônia do Sacramento, onde se achava quando apareceu a revolução daquela Província. Neste ponto, que foi o teatro da guerra, defendeu constantemente a causa de sua Pátria; era o comandante não só de todos os artilheiros como de uma Bateria quando o almirante Brown atacou com todas as suas forças aquela Praça, donde foi rechaçado depois de um combate desesperado, em 26 de fevereiro de 1826; e não só neste como no segundo de 2 de março quando o Almirante voltou com novas forças e empenhou outra ação igualmente terrível; assim como no ataque em que o General Lavalhega com 800 homens apresentou em 13 do dito mês e ano contra a pequena guarnição daquela Praça. O Suplicante se achou constantemente, bem como em todas as outras de inferior natureza, merecendo por estes serviços, que absolutamente não lhe poderão negar, a decoração do Cavaleiro da Ordem do Cruzeiro Imperial. Mas, como o ódio de sua pessoa era inconciliável no coração dos inimigos do Brasil, o comandante 
do seu respectivo corpo, que se achava em Monte Vídeo, fez uma promoção e postergou nela o Suplicante dando o posto que lhe pertencia a um outro $2^{\circ}$ Tenente, português, muito mais moderno serviço e que se achava debaixo do seu comando naquele destacamento; esta pretensão tão injusta como escandalosa, motivou as repetidas queixas que o suplicante levou ao conhecimento do governo dos Bourbon, e que ele sabia nunca seriam atendidas porque na guia que era necessária juntar aos seus documentos, iaô escritos o nome, a pátria, e a filiação do suplicante, o que com efeito assim sucedeu, porque os ministros daquele Governo trataram com despachos antigos, como por exemplo: junte documentos; indo esses juntos, torna o Suplicante a enviar novos documentos e tem por despacho: remetido ao Visconde de Camamú para ser contemplada em proposta geral sem prejuízo - promoção esta que nunca se vê efeito. Finalmente, cansado o Suplicante e falto de recursos e meios para continuar com a pretensão de sua justiça, cedeu as circunstâncias e resignouse com a sua má fortuna, esperando um dia de melhoramento com a queda indubitável de um governo despótico.

A Junta e o seu presidente solicitaram a transferência dessas tropas para Pernambuco, argumentando que a saída dos corpos militares portugueses com Luís do Rego desfalcou corpos da guarnição e seria muito mais oneroso fazer um novo recrutamento, em uma economia desorganizada. Pelo menos até o término do seu governo, não foram atendidos em sua solicitação. Outra questão discutida dizia respeito às tropas portuguesas aquarteladas no Brasil que continuavam sendo pagas pela província, independente do lugar onde estivessem.

A reforma administrativa que o governo de Gervásio Pires colocava em pauta dependia de uma série de medidas do governo de Lisboa, como, por exemplo, a Reforma da Alfândega do Algodão. Esta correspondia a uma modificação no sistema da arrecadação e remanejamento de funcionários para os novos cargos criados, sem, contudo, serem contratados novos funcionários. Outros itens da reforma referiam-se à diminuição ou extinção de alguns dos impostos, a criação de um tribunal de Relação, o estabelecimento de uma Academia Literária e o aumento dos soldos da tropa.

Tanto a defesa do tribunal de Relação como a do estabelecimento da Academia Literária estavam fundamentadas nos benefícios que trariam à população: em toda a província havia apenas dois juízes letrados, um em Goiana, que acabara de fugir, e outro em Recife. Em Olinda, a capital, o juiz era ordinário. A Junta solicitava Juízes de Fora para os lugares indicados e a criação de uma Relação para o final Julgado dos pleitos civis e criminais, 
que se encontravam estagnados, informava Gervásio Pires. O argumento que usava para a implantação da Academia Literária era no sentido de evitar que os empregados civis, literários ou fiscais, fossem obrigados a viajar duas mil léguas até Lisboa para prestar exames, denunciando a desigualdade de condições entre membros de uma mesma sociedade.

A maioria dessas propostas implicava despesas que deveriam ser sustentadas pela arrecadação. Cobrar impostos no Brasil já era a origem de convulsão social e não convinha politicamente acrescentar nenhum novo tributo. Registre-se que a Junta propunha a abolição de uns impostos e a diminuição de outros, o que, politicamente, era um desencontro ao mesmo tempo com o governo do Rio e com o governo de Lisboa.

Em 2 de junho de 1822, o presidente da província apresentou ao ministro da Fazenda Nacional a situação econômico-financeira do erário, enumerando a causa dos males que a afligiam: o governo se ressentia da perda das Comarcas de Alagoas e do Rio Grande do Norte, o que acarretava a diminuição na arrecadação dos rendimentos fiscais. Antes da Revolução de 1817, a receita da província atingira o montante de 1.216:000\$000. A principal fonte da receita era a arrecadação dos dízimos do açúcar e do algodão e do direito de saída deste produto, além do direito de entrada das fazendas e o subsídio militar das carnes. Dizia Gervásio que, sabendo-se que o montante do dízimo depende do valor do produto e o subsídio depende da abundância, por haverem caído de preço o açúcar e o algodão e, havendo falta de gados, a receita da província decaiu consideravelmente. O presidente da província denuncia a justificativa dos devedores fiscais, escudada em um entendimento propositalmente errado: segundo eles, "a constituição é isenção de direito, é liberdade indefinida".

$\mathrm{Na}$ realidade, reclamava o presidente da Junta que a província havia arcado com despesas além de sua receita, marcada pela diminuição dos lucros na sua produção, seja pela redução dos preços de seus produtos, seja pelo excesso de impostos e ainda pelas obrigações com os corpos militares. Em um curto espaço de tempo, pagara as despesas da vinda e do regresso de dois batalhões de Portugal, além de fardamentos e soldos adiantados. As dívidas, de fato, eram elevadas, mas por "justiça e política" dever-se-iam aumentar os ordenados dos professores das primeiras letras e latinidade, dos empregados fiscais e, também, o soldo da tropa.

Observando-se os dados referentes aos tributos que incidiam sobre os produtos de aguardente, vê-se que os responsáveis por estes produtos não 
tinham representação política e econômica suficiente em Lisboa ou mesmo na província para evitar uma exação asfixiante. Sabe-se que os médios proprietários de engenhos aproveitavam parte da colheita de cana-de-açúcar, nem sempre muito rentável, e a destinavam à produção de aguardente, produto lucrativo e muito procurado pelas tropas portuguesas quando sediadas na colônia. Com a guerra da Independência e a saída dos contingentes militares portugueses, perderam os produtores seus maiores consumidores.

O estado de rebeldia, quase permanente na colônia, pode ser também entendido a partir das reclamações dos médios proprietários, que tinham suas economias baseadas na produção de aguardente, no abate das carnes e nas informações sobre a economia, de uma maneira geral. Os grandes proprietários, em sua maioria, não foram os líderes mais importantes das grandes rebeliões e revoluções. No rol dos réus, nas devassas, são encontrados, mas a participação deles é menor, comparativamente aos médios e pequenos proprietários, comerciantes e militares.

As queixas não eram apenas do governo da Junta de Pernambuco; autoridades de outras províncias também reclamavam da situação tributária e se dirigiam ao rei sobre a matéria. D. João VI autorizou as Juntas Provisórias a entrarem em acordo com as Juntas da Fazenda, e depois de consultar as Câmaras respectivas, poderiam extinguir os impostos estabelecidos sobre as carnes verdes, farinha de mandioca e selo das heranças e legados, mas não autorizou a dispensa dos impostos sobre os alambiques e as aguardentes.

Avaliando o que foi solicitado e o que foi atendido, conclui-se que os membros das Juntas tinham razão, quando escreveram de maneira lastimosa ao rei, afirmando que estavam "condenados ao abandono".

Entre os dois centros de poder, a Junta presidida por Gervásio Pires prestigiou, em todos os seus atos, as cortes, o rei, enfim, Lisboa; entretanto, sentia-se desamparada na sua política contrária à Independência defendida pelo Rio de Janeiro. Da província saíam tributos que alimentavam os cofres para pagamento da polícia e da iluminação do Rio de Janeiro. Os grandes proprietários não eram atingidos por essa política de arrocho fiscal. Talvez seja compreensível a retirada do apoio da elite secundária, constituída pelos pequenos e médios proprietários, ao governo de Gervásio Pires. Sem o suporte de Lisboa, este grupo passou a apoiar o Rio de Janeiro. Contando apenas com os comerciantes, Gervásio Pires se tornou alvo fácil da política do Rio de Janeiro e de eventuais motins dos militares. 
A voz de Clemente Pereira fazia-se presente na imprensa, defendendo a permanência do príncipe dentro de um projeto que interessava aos fluminenses e paulistas; todavia, não contava com a adesão dos pernambucanos. Segundo aquele político, Pernambuco, guardando as matérias-primas da Independência, que proclamou um dia, malograda por imatura, mas não extinta, quem duvida a levantará de novo?

Ouvindo os áulicos, a política do regente foi, então, não comunicar à Junta qualquer informação ou alteração. A decisão de D. Pedro em permanecer no Brasil chega ao conhecimento do governo presidido por Gervásio Pires, através de periódicos vindos da Província do Rio de Janeiro. A resposta ao regente é imediata, de apoio à permanência do príncipe, desde que seja para unir as províncias e, assim mais forte, fazer a união delas com Portugal. Há, entretanto, repúdio ao projeto de "recolonização" do Governo Executivo de Lisboa iniciado pelo envio de tropas portuguesas ao Brasil, pelas nomeações dos Governadores de Armas, dos comandantes de Marinha e dos Administradores da Justiça; estas autoridades responderiam, apenas, a Lisboa; os governos provinciais não seriam ouvidos nessa matéria. Lembra Gervásio que as províncias do Brasil são muito diferentes entre si e também das de Portugal, em extensão, clima, costumes, proximidade do poder. Por esse decreto, os presidentes de Juntas Governativas serão obrigados a recorrer ao Reino em questões insignificantes. Reclama, ainda, no documento, da restauração da Mesa de Inspeção, já abolida pela sua inutilidade. Pede desculpas por ter se antecipado aos irmãos paulistas no envio de uma representação de protesto ao Soberano Congresso.

Em outras correspondências ao regente, a Junta de Pernambuco defende um "sistema liberal fundado no direito natural e no direito das gentes e conforme as luzes do século" capaz de realizar a obra da união com Portugal. A idéia de separação de Portugal ou de independência, tendo a hegemonia do Rio de Janeiro sobre as outras províncias brasileiras, não foi defendida pela Junta presidida por Gervásio.

Os ofícios de 18 e 26 de março de 1822 confirmam a posição de Pernambuco: "tão francos quanto firmes e leais aos juramentos de obediência às Cortes, a El Rei e a Vossa Alteza Real em tudo que se não opuser a sua soberana vontade". Os áulicos faziam outra leitura. A Junta foi acusada de "corcunda", vendida aos portugueses. 
A deposição de Gervásio Pires foi uma trama bem urdida entre os partidários da Independência liderada pelo Rio de Janeiro e os grandes e médios proprietários de terras. Reconhecido e preso na Bahia, posteriormente foi enviado, junto com o filho José Pires, para Lisboa, onde foram encarcerados no Limoeiro. Fora acusado de crime vago de lesa-nação, por não ter acatado as ordens do rei D. João VI. Na realidade ele foi acusado por trinta testemunhas pelos seguintes fatos: por ter retirado de Pernambuco as tropas portuguesas enviadas pelas cortes e pelo rei; por ter assinado o termo de vereação da Câmara do Recife, de $1^{\circ}$ de junho, pelo qual se declarou a independência do poder executivo do Brasil, na pessoa do príncipe D. Pedro; porque, como presidente de um governo que dependia das cortes e do rei, deu ordens para a eleição de deputados às cortes do Brasil e porque, tendo o governo do Rio de Janeiro declarado guerra a Portugal, aliou-se aos rebeldes.

Em Pernambuco, Gervásio foi acusado e deposto por não aderir à causa do Brasil; na Bahia, foi preso pelas forças do general Madeira e enviado à prisão do Limoeiro em Lisboa. Injuriado e processado pelos dois grupos que disputavam o poder, mais uma vez uma contra-revolução em Portugal, a de 5 de junho de 1823, resgatou-lhe a liberdade. É interessante observar que os seus verdadeiros inimigos não aparecem como responsáveis por sua punição; foram exatamente os seus supostos aliados que o incriminaram e o privaram de sua liberdade.

Ao presidir a Junta em um momento de desestruturação da Província de Pernambuco, ou seja, desligada dos centros políticos de poder, tentou, com ardis políticos, prolongar a "independência de Pernambuco" tanto do Rio de Janeiro quanto de Lisboa.

Através de um processo complexo e com base no Decreto de 6 de junho de 1823, que proibia processos fundamentados em opiniões políticas, a devassa contra Gervásio foi dada por nula. Em 14 de junho de 1823, Gervásio Pires foi posto em liberdade e se dirigiu ao Rio de Janeiro. Apesar de fazer parte do grupo de liberais que esteve à frente da Confederação do Equador, seu nome não aparece como um dos réus. Mas é por intermédio da imprensa que sabemos da sua recuperação econômica: instalou uma fábrica de descaroçar algodão, de fiar e tecer panos. Obteve vantagens pecuniárias para a montagem da fábrica, que produzia cobertores e algodãozinho, competindo com similares estrangeiras. Na trajetória de sua vida privada aparece em 1827 como 
proprietário do engenho Bulhões, não para se tornar um senhor-de-engenho, mas para edificar uma nova fábrica.

O nome de Gervásio Pires Ferreira aparecerá ainda na política do Império. Em 1826, na primeira eleição para o Senado, da qual Pernambuco participou, foi eleito senador. Na seqüência, elegeu-se conselheiro da província, conselheiro do governo, deputado à Assembléia Geral, na Legislatura de 1830 a 1833, e membro da Assembléia Legislativa Provincial.

Dos vários projetos de que participou registramos os seguintes: a Lei de 4 de outubro de 1831, que criou o Tesouro e as Tesourarias Provinciais, a Lei do Orçamento de 15 de dezembro de 1830 e o Código de Processo Criminal.

Na tumultuosa sessão da Assembléia Geral dos Deputados em 1832, Gervásio Pires desempenhou um papel importante, escreveu Pereira da Costa: ${ }^{11}$ participou, juntamente com Francisco de Paula Araújo, Cândido Batista de Oliveira, Manoel Odorico Mendes e Gabriel Mendes dos Santos, da Comissão que estudou a matéria relacionada com a demissão da Regência Trina e dos ministros de Estado.

A sua vida política, na província, foi exercida com toda plenitude. Ocupou por muito tempo o cargo de conselheiro do governo da Província de Pernambuco, propondo ou apoiando medidas de interesse da província, como, por exemplo, o projeto de melhoramento do Porto.

Faleceu aos 71 anos de idade, na cidade do Recife, em 9 de março de $1836 .^{12}$

${ }^{11}$ Costa, Pereira da. Dicionário biográfico de pernambucanos célebres, Fundação de Cultura Cidade do Recife, 1981.

${ }^{12} \mathrm{Na}$ elaboração desse artigo, foram ainda utilizadas as seguintes obras: Valentim Alexandre, Os sentidos do Império. Questão nacional e questão colonial na crise do Antigo Regime português, Porto, Portugal, Edições Afrontamento, 1993; ATAS do Conselho do Governo de Pernambuco, vols. 1 e 2, Arquivo Público Estadual Jordão Emerenciano, Recife, Editora CEPE, 1997; Irene Castels, La Utopia Insurrecional del Liberalismo, Barcelona, Editorial Crítica, 1989; Hipólito José da Costa, 1774-1823, Organização e introdução de Sergio Góes de Paula, São Paulo, Editora 34, 2001; Pereira da Costa, Anais pernambucanos, vol. 3, Arquivo Público Estadual de Pernambuco, Recife, Secretaria de Interior e Justiça, 1952; Socorro Ferraz, Liberais \&̈ Liberais. Guerras civis em Pernambuco no século XIX, 1996; Silvestre Pinheiro Ferreira, Idéias políticas, PUC, Rio de Janeiro, 1976; Antonio Joaquim de Melo, Biografia de Gervásio Pires Ferreira, vols. 1 e 2, Recife, Editora Universitária da UFPE, 1973 \& Obras políticas e literárias de Frei Joaquim do Amor Divino Caneca, tomo 1, Recife, Typographia Mercantil, 1875; C. Rizzini, Hipólito da Costa e o Correio Brasiliense, São Paulo, Companhia Editora Nacional, 1957. 